ORIGINAL PROF-2113

\title{
ACUTE CORONARY SYNDROME;
}

Frequency of hypomagnesaemia in patients.

Dr. Muhammad Sohail Anjum, Dr. Shahid lqbal, Dr. Naila Kalsoom, Mbbs, Dr. Hira Manzoor

ABSTRACT... Introduction: Magnesium is the fourth most abundant cation in the body and the second most abundant intracellular cation after potassium. Magnesium plays a fundamental role in many functions of the cell, including energy transfer, storage, and uses protein, carbohydrate, and fat metabolism; maintenance of normal cell membrane function; and the regulation of parathyroid hormone (PTH) secretion. Objective: To determine the frequency of hypomagnesaemia in patients presenting with acute coronary syndrome (ACS). Design: Cross -sectional study. Place and duration: Coronary Care Units and medical ward in Allied Hospital Faisalabad, from 26-012010 to 25-07-2010. Settings: The study was conducted in medical unit II and coronary care unit of Allied Hospital Faisalabad. Sample Size: Sample size was calculated by using WHO sample size calculator taking confidence level 95\%, population proportion $7.7 \%$ and required precision $4 \%$. Sample size $n=171$. Sampling Technique: Non-probability consecutive sampling. Method: A total of 171 patients fulfilling the criteria of ACS admitted in M-II and CCU were enrolled in the study, demographic details, history and clinical examination of the patients were recorded. Blood sample was collected in estimation of serum magnesium level. Results: In this study the mean serum magnesium was $1.59 \pm 8.380$ in males and $1.56 \pm 7.678$ in females. Among the 171 acute coronary syndrome patients, 14 (8.2\%) were diagnosed with hypomagnesaemia. There were 8 (8.8\%) male and 6(7.5\%) female patients. 157 (91.8\%) patients did not have hypomagnesaemia out of $83(91.2 \%)$ were male and 74 (92.5\%) were female patients. There was male predominance. Male to male ratio was 1.33:1. Conclusions: The results showed that frequency of hypomagnesaemia in acute coronary syndrome was significantly high and comparable to other studies. There was male preponderance. However, there was variation in the occurrence of hypomagnesaemia in acute coronary syndrome. Early assessment of serum magnesium concentration is needed in acute coronary syndrome in order to implement proper magnesium supplementation.

Key words: Hypomagnesaemia, parathyroid hormone, Acute coronary syndrome

Article Citation

$\checkmark \quad$ Anjum MS, lqbal S, Kalsoom N, Manzoor H. Frequency of hypomagnesaemia in patients with acute coronary syndrome. Professional Med J Feb 2013;20(1):034-038.

\section{INTRODUCTION}

Magnesium is the fourth most abundant cation in the body and the second most abundant intracellular cation after potassium ${ }^{1}$. Hypomagnesaemia has been directly implicated in hypokalemia, hypocalcaemia and dysrrthymias ${ }^{2}$. Several factors may impair renal reabsorption, such as volume expansion, ethanol ingestion, hypercalcemia, and diuretic administration (e.g. osmotic, thiazide, loop) ${ }^{3}$. Moreover, Magnesium may play a role in acute coronary syndromes, acute cerebral ischemia, and asthma. Cardiac arrhythmias may occur, including sinus tachycardia, other supraventricular tachycardia, and ventricular arrythmias. Electrocardiographic abnormalities may include prolonged PR or QT intervals-wave flattening or inversion, and ST straightening ${ }^{4}$. Prevalence of hypomagnesaemia in acute coronary syndrome is
$7.7 \%{ }^{5}$. Altered magnesium balance can be found in diabetes mellitus, chronic renal failure, nephrolithiasis, osteoporosis, aplastic osteopathy, and heart and vascular disease. Hypomagnesemia can, by itself, induce hypokalemia (often refractory to potassium repletion until $\mathrm{Mg}$ deficit is corrected), neuromuscular irritability, tetany, seizures, depression, carbohydrate intolerance, hypocalcemia, digoxin cardiotoxicity, and tachyarrhythmias resistant to standard therapy, and they respond only to $\mathrm{Mg}$ repletion. For this reason, in clinical conditions such as pre-eclampsia, acute myocardial infarction, tachycardia torsade de pointes, etc., intravenous Mg treatment is advocated ${ }^{6}$.

The rationale of my study is that hypomagnesaemia in acute coronary syndrome is common and predispose the person for development of serious cardiac 
arrhythmias. This poses a great risk for cardiovascular events and deaths.

\section{SUBJECTS AND METHODS}

The study was conducted in medical unit II and coronary care unit of Allied Hospital Faisalabad.

Sample size was calculated by using WHO sample size calculator taking confidence level $95 \%$, population proportion $7.7 \%$ and required precision $4 \%$. Sample size $\mathrm{n}=171$.

171 patients with acute coronary syndrome admitted in Medical Unit II and Coronary Care Unit of Allied Hospital Faisalabad having characteristic chest pain, ECG changes, positive cardiac enzymes and Cardiac Troponin T were included in cross -sectional study after approval from hospital ethical committee and taking informed consent. Patients on diuretics, alcoholics, Malabsorption, Laxative abuse and Malnutrition were excluded. $5 \mathrm{ml}$ blood from peripheral vein on admission and sent to the laboratory of Allied Hospital for the measurement of magnesium reported by pathologist by using microlab 300 processing apparatus. Data collected and calculated on proforma.

\section{RESULTS}

A total of 171 patients, 91 males and 80 females met inclusion criteria. In this study the mean age of the patients was $51.62 \pm 6.364$ years. There were 8 $(4.7 \%)$ patients in the age range of 31-40 years, 66 $(38.6 \%)$ patients in the age range of $41-50$ years,
$74(43.3 \%)$ patients in the age range of $51-60$ years, and $23(13.5 \%)$ patients in the age range of $61-70$ years. A total of 171 patients were included in the study. There were 91 (53.20\%) male patients and $80(46.8 \%)$ female patients.

In this study the mean serum magnesium was 1.59 \pm 8.380 in males and $1.56 \pm 7.678$ in females (TableI). Among the 171 acute coronary syndrome patients, $14(8.2 \%)$ were diagnosed with hypomagnesaemia. There were $8(8.8 \%)$ male and $6(7.5 \%)$ female patients. $157(91.8 \%)$ patients did not have hypomagnesaemia out of $83(91.2 \%)$ were male and $74(92.5 \%)$ were female patients. There was male predominance. Male to female ratio 1.33:1.

Regarding components of acute coronary syndromes, ST segment elevation myocardial infarction was most common, $60.8 \%$ (males $=60.4 \%$, females $=$ $61.30 \%$ ) ,Non-ST segment elevation myocardial infarction was $11.7 \%$ (males $=8.8 \%$, females $=$ $16.3 \%$ ), and unstable angina was $27.05 \%$ (males $=$ $30.80 \%$, females $=22.50 \%$. (table II-III, Figure 1 ). . The frequency of metabolic syndrome was highest in patients presenting as ST segment elevation myocardial infarction. Out of 14 with Hypomagnesaemia, $7(50.0 \%)$ had ST- segment elevation myocardial infarction, 4(28.6\%) had unstable angina and $3(21.4 \%)$ had non ST-segment elevation myocardial infarction. (table IV).

\begin{tabular}{|ll|c|c|c|c|}
\hline \multicolumn{1}{|c|}{ Sex } & Frequency & Percent & Valid Percent & Cumulative Percent \\
\hline Male & Valid less serum & & & & \\
& Mg & 8 & 8.8 & 8.8 & 8.8 \\
& Equal or more serum Mg & 83 & 91.2 & 91.2 & 100.0 \\
& Total & 91 & 100.0 & 100.0 & \\
Female & Valid less & 6 & 7.5 & 7.5 & 7.5 \\
& Equal or more & 74 & 92.5 & 92.5 & 100.0 \\
& Total & 100.0 & 100.0 & \\
& 80 & &
\end{tabular}




\begin{tabular}{|c|c|c|c|c|c|}
\hline & & Frequency & Percent & Valid Percent & Cumulative Percent \\
\hline Valid & $\begin{array}{l}\text { ST segment elevation myocardial infarction } \\
\text { Non-ST segment elevation myocardial } \\
\text { infarction }\end{array}$ & $\begin{array}{c}104 \\
20\end{array}$ & $\begin{array}{l}60.8 \\
11.7\end{array}$ & $\begin{array}{l}60.8 \\
11.7\end{array}$ & $\begin{array}{l}60.8 \\
72.5\end{array}$ \\
\hline & $\begin{array}{l}\text { Unstable angina } \\
\text { Total }\end{array}$ & $\begin{array}{c}47 \\
171\end{array}$ & $\begin{array}{c}27.5 \\
100.0\end{array}$ & $\begin{array}{c}27.5 \\
100.0\end{array}$ & 100.0 \\
\hline
\end{tabular}

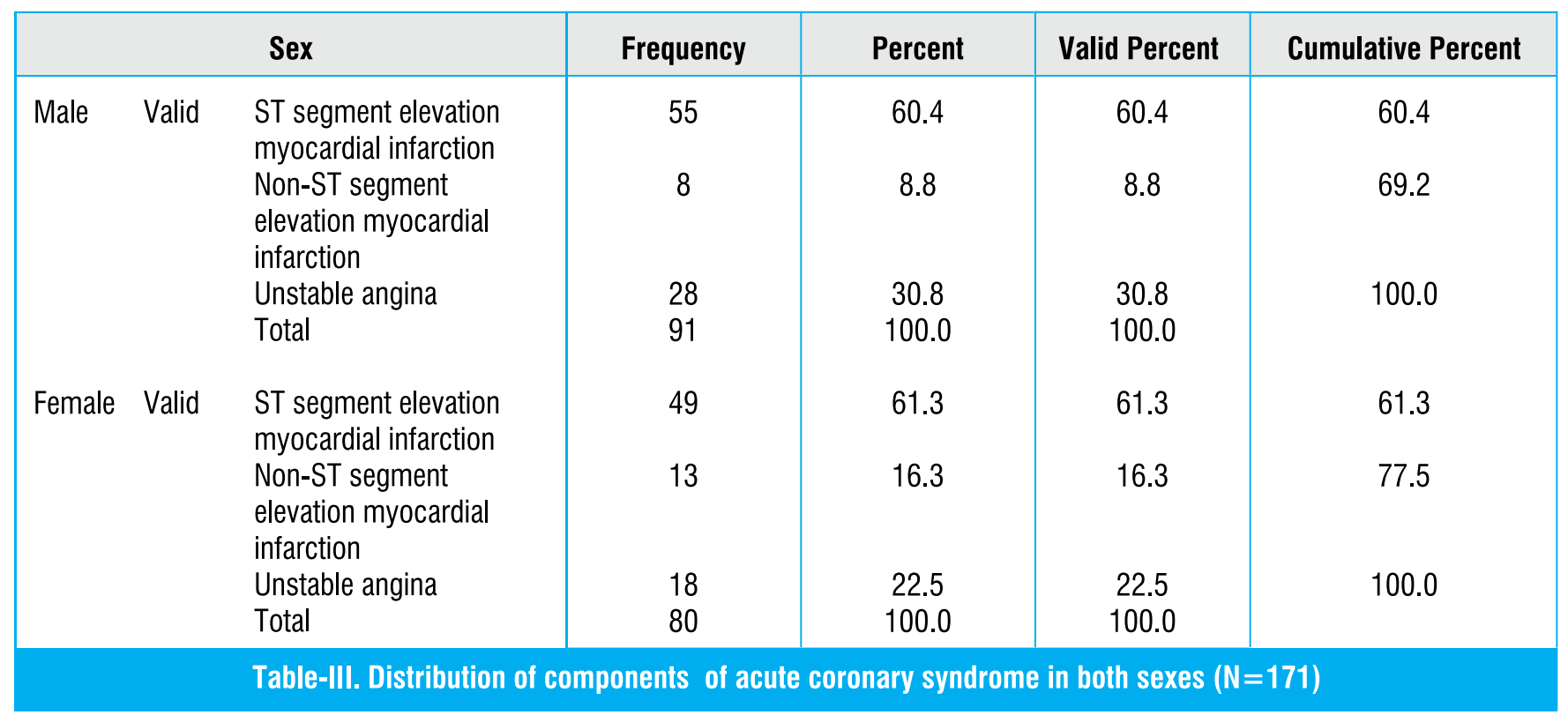

\begin{tabular}{|c|c|c|c|c|c|}
\hline \multicolumn{2}{|r|}{ Sex } & \multirow{2}{*}{$\begin{array}{c}\text { Frequency } \\
\qquad \begin{array}{c}7 \\
3\end{array}\end{array}$} & \multirow{2}{*}{$\begin{array}{l}\text { Percent } \\
50.0 \\
21.4\end{array}$} & \multirow{2}{*}{$\begin{array}{c}\begin{array}{c}\text { Valid } \\
\text { Percent }\end{array} \\
50.0 \\
21.4\end{array}$} & \multirow{2}{*}{$\begin{array}{c}\begin{array}{c}\text { Cumulative } \\
\text { Percent }\end{array} \\
50.0 \\
71.4\end{array}$} \\
\hline Less & $\begin{array}{l}\text { ST segment elevation myocardial infarction } \\
\text { Non-ST segment elevation myocardial } \\
\text { infarction } \\
\text { Unstable angina } \\
\text { Total }\end{array}$ & & & & \\
\hline Equal or more & $\begin{array}{l}\text { ST segment elevation myocardial infarction } \\
\text { Non-ST segment elevation myocardial } \\
\text { infarction } \\
\text { Unstable angina } \\
\text { Total }\end{array}$ & $\begin{array}{c}97 \\
18 \\
42 \\
157\end{array}$ & $\begin{array}{c}61.8 \\
11.5 \\
\\
26.8 \\
100.0\end{array}$ & $\begin{array}{c}61.8 \\
11.5 \\
26.8 \\
100.0\end{array}$ & $\begin{array}{r}61.8 \\
73.2 \\
100.0\end{array}$ \\
\hline
\end{tabular}




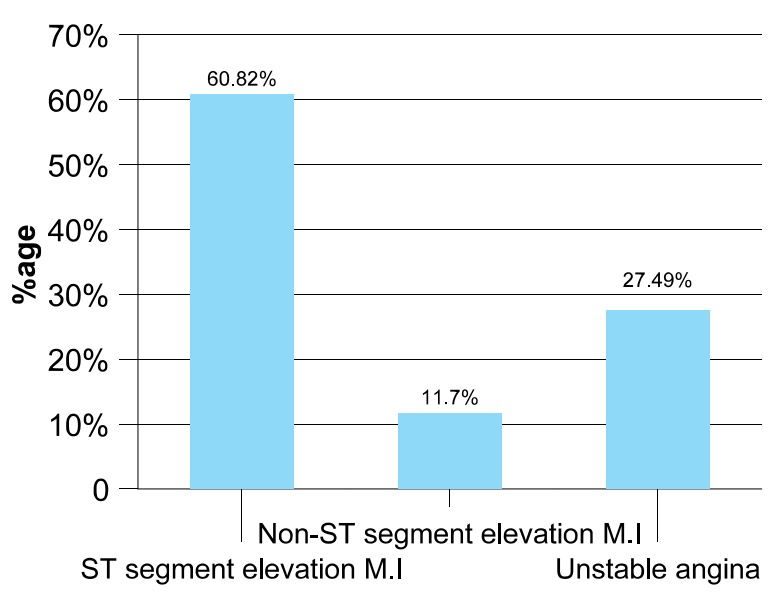

Acute_Coronary_Syndrome

\section{Fig-1. Distribution of components of acute} coronary syndrome

\section{DISCUSSION}

Ahmad $\mathrm{A}$ et $\mathrm{al}^{7}$ conducted a study to determine the significance of serum magnesium and electrolyte levels in acute myocardial infarction in first six hours in 88. It was concluded from this study that there was statistically significant hypomagnesemia $(P<0.001)$ in the patients of AMI at the time of admission. It was also noted that there was significant hypokalemia in AMI patients $(P<0.05)$ over the age of 60 years.

Landmark $\mathrm{K}$ and Urdal $\mathrm{P}^{8}$ studied serum magnesium and potassium in acute myocardial infarction and their relationship to existing â-blockade and infarct size. In there study These observations suggest that the initial drop in s-Mg and s-K in the early phase of AMI is due to increased stimulation of â2-adrenergic receptors; these changes can be prevented partly or completely by the use of nonselective â-blockers.

Rasmussen HS et $\mathrm{al}^{9}$ conducted a double blind placebo controlled study in 130 patients to find the role of magnesium infusion in reducing the incidence of arrhythmias in acute myocardial infarction. It was concluded that magnesium infusion in the postinfarct period reduced the incidence of supraventricular tachyarrhythmias. Ceremuyski L and Hao NV ${ }^{10}$ studied the role of hypomagnesamia in ventricular arrhythmias late after myocardial infarction in 118 patients. They suggested that supplementation with $\mathrm{MgSO}_{4}$ would be a reasonable approach to the treatment of predischarge complex ventricular arrhythmias after MI. Al-Muhammadi $\mathrm{MO}^{11}$ conducted a study of 48 patients with acute myocardial infarction (AMI) and healthy subjects of both sexes and found that serum magnesium and zinc concentration of both male and female AMI patients showed significant decrease(in male , $P<0.05 ; P<0.01$ and in female, $P<0.01$; $P<0.01$, respectively) in comparison with control.

Hypomagnesaemia is preventable and, identifying this at early stage at emergency wards and coronary care units might be of significant help. Then subsequent supplementation with $\mathrm{MgSO}_{4}$ would be a reasonable approach to the treatment of predischarge complex ventricular arrhythmias after MI.

\section{REFERENCES}

1. Drueke TB, Lacour B. Magnesium homeostasis and disorders of magnesium metabolism. In: Feehally $\mathrm{J}$, Floege J, Johnson RJ, (editors). Comprehensive clinical nephrology. 3rd ed. Philadelphia: Mosby; 2007:136-8.

2. Gupta, Shailja, Sodhi S, Kaur J, Yamini J. Improvement in electrolyte imbalance in critically ill patient after magnesium supplementation-A case report. Indian J Clin Biochem 2009; 24(2):208-10.

3. Apa H, Kayserili E, Agin H, Hizarcioglu M, Gulez P, Berdeli A. A case of hypomagnesaemia with secondary hypocalcaemia caused by Trpm6 gene mutation. Indian J Pediatr 2008; 75:632-4.

4. Bringhurst FR, Demay MB, Krane SM, Kroneberg HM. Bone and mineral metabolism. Health and disease. In : Kasper DL, Follci AS, Longo DL, Brauwold E, Havser SL, Jameson JL, (editors). Harrison principles of internal medicine. Vol.Il. 16th ed. New York: McGraw-Hill, 2005:2238-49.

5. John RP, Assad M. Magnesium disorders and 
cardiovascular diseases. J Clin Cardiol 1992; 5: 55668.

6. Musso CG. Magnesium metabolism in health and disease. Int Urol Nephrol 2009;41:357-62.

7. Ahmad A, Akram M, Tanveer ZH, Ahmad I, Masud S. Significance of serum magnesium and electrolyte levels in acute myocardial infarction in first six hours. PakJ Cardiol 2006;17:25-9.

8. Landmark K, Urdal P. Serum magnesium and potassium in acute myocardial infarction: relationship to existing â-blockade and infarct size. ANGIOLOGY May 1993; 44: 347-52.

9. Rasmussen HS, Suenson M, Mcnair $P, N$ rreg rd $P$, Balslev $S$. Magnesium infusion reduces the incidence of arrhythmias in acute myocardial infarction. A double-blind placebo-controlled study. Clin Cardiol 1987;10:351-6

10. Ceremuyski L, Hao NV. Ventricular arrhythmias late after myocardial infarction are related to hypomagnesemia and magnesium loss: Preliminary trial of corrective therapy. Clin Cardiol 1993; 16:4936.

11. Al-Muhammadi MO. Some physiological changes in men and women after an acute myocardial infarction. QMJ 2011;7(12):76-97.

\section{AUTHOR(S):}

1. DR. MUHAMMAD SOHAIL ANJUM

M.B.B.S, MRCP (UK), MRCP (LONDON), FCPS (Medicine) Assistant Professor of Medicine Independent Medical College, Faisalabad

2. DR. SHAHID IQBAL

M.B.B.S, FCPS (Medicine)

Assistant Consultant

King Fahad Medical City, Riyadh

3. DR. NAILA KALSOOM, MBBS

Medical Officer

National Hospital, Faisalabad.
4. Dr. Hira Manzoor, MBBS

Fatima Jinnah Medical College, Lahore.

Correspondence Address:

Dr. Muhammad Sohail Anjum P-353, Street No.12, Taj Colony, Sargodha Road,Behind MTM, Faisalabad.

friendsohail712@gmail.com

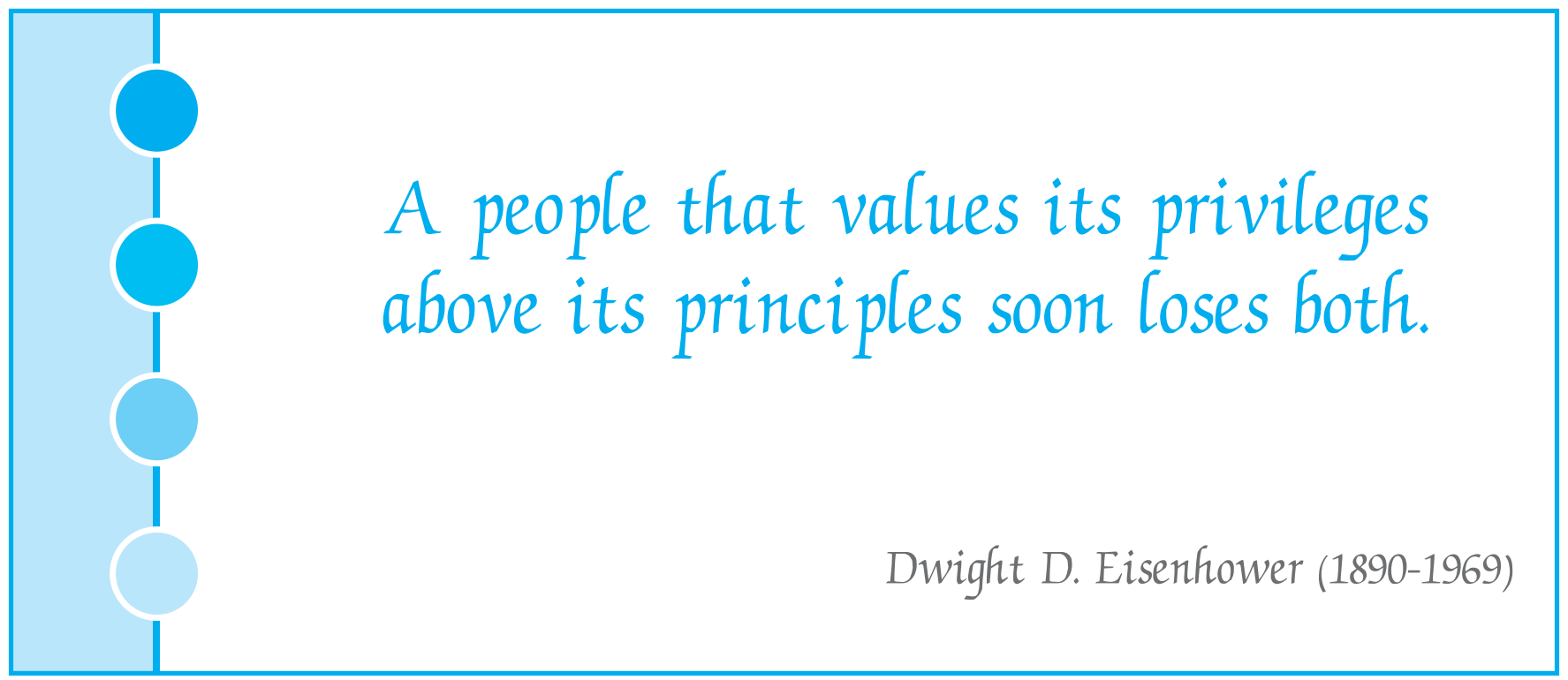

